\title{
Typomorphic Characteristics of Pyrites from the Shuangwang Gold Deposit, Shaanxi, China: Index to Deep Ore Exploration
}

\author{
Jianping Wang * ${ }^{(\mathbb{C}}$, Zhenjiang Liu, Kexin Wang, Xiangtao Zeng, Jiajun Liu and Fangfang Zhang \\ School of Earth Sciences and Resources, China University of Geosciences, Beijing 100083, China; \\ lzj@cugb.edu.cn (Z.L.); wangkexin10209@163.com (K.W.); zengxiangtao2008@163.com (X.Z.); \\ liujiajun@cugb.edu.cn (J.L.); zff@cugb.edu.cn (F.Z.) \\ * Correspondence: jpwang@cugb.edu.cn; Tel.: +86-10-8232-2264
}

Received: 23 May 2019; Accepted: 21 June 2019; Published: 25 June 2019

check for updates

\begin{abstract}
The large Shuangwang gold deposit (>80 t gold) is located in the Western Qinling Orogen (WQO) of central China. It is an orogenic-type gold deposit hosted in an NW-extending breccia belt in the Devonian Xinghongpu Formation. Gold mineralization of the Shuangwang deposit is featured by hydrothermal breccia ores with strata fragments cemented by hydrothermal minerals dominated by ankerite, quartz, and pyrite with minor amounts of calcite and albite. Pyrite is the major gold-hosting sulfide and the most abundant ore mineral. Crystal habits, thermoelectricity, and trace-element composition of pyrites from the main ore-forming stage of the Shuangwang gold deposit were studied by microbinocular, BHTE-06 thermoelectric coefficient measuring instrument, and high-resolution inductively coupled plasma mass spectrometry (HR-ICP-MS). Spatial distribution of the above data for pyrites was delineated by contour maps of morphology index, P-type frequency, and primary halo elements (e.g., supraore halo elements $\mathrm{Ba}$ and $\mathrm{Sb}$; near-ore halo elements $\mathrm{Pb}, \mathrm{Zn}$, and $\mathrm{Cu}$; and subore halo elements $\mathrm{Co}, \mathrm{Mo}$, and $\mathrm{Bi}$ ). Based on the above results, four target areas (areas between prospecting lines 0 and 1, between lines 14 and 18 below orebody KT9; areas between prospecting lines 30 and 34, between lines 44 and 46 below orebody KT8) were put forward for deep gold exploration in the future. These targets are consistent with the depth extrapolation of proven gold orebodies, indicating the practicality of typomorphic characterization of pyrites as vector to deep/concealed gold orebodies. The effectiveness of the pyrite typomorphic parameter for deep gold prediction seems to be chemical composition, crystal habits, and then thermoelectricity.
\end{abstract}

Keywords: pyrite typomorphic characteristics; crystal habit; thermoelectricity; trace element; Shuangwang gold deposit

\section{Introduction}

Pyrite is one of the most common gold-bearing sulfides in a series of hydrothermal gold deposits, such as orogenic-type, Carlin-type, and epithermal-type gold deposits [1-5]. The typomorphic characteristics of pyrite, e.g., crystal habit, thermoelectricity, and chemical composition are generally controlled by geochemical conditions during ore-forming processes. Thus, typomorphic characteristics of pyrite can not only be used in studying the genesis of gold-ore deposits [2,3] but also for gold-ore exploration [6,7], especially for deep ore predictions $[8,9]$.

The Shuangwang gold deposit is a large orogenic gold deposit $(>80 \mathrm{t} \mathrm{Au})$ in the Western Qinling Orogen (WQO). It occurs in the Devonian strata and is characterized by breccia-type mineralization [10]. Orebodies KT8 and KT9 are the two major orebodies that account for $>75 \%$ of the total gold reserve [11,12] of the Shuangwang gold deposit. Most of the shallow reserve has been extracted after 
more than 35 years of operation. Thus, it is urgent to find more gold at depth for the development of the Shuangwang gold mine. The present study focuses on the typomorphic characteristics of gold-bearing pyrite and its application to deep ore targeting in the Shuangwang gold deposit.

\section{Geologic Setting}

The WQO, sandwiched between the North China Block (NCB) to the north and South China Block (SCB) to the south (Figure 1), is part of the Central Orogenic Belt of China [13-15]. Due to the $\mathrm{N}-\mathrm{S}$ directional orogenic processes, regional tectonic lines extend in the E-W direction, represented by the Shang-Dan and Mian-Lue sutures and many folds and faults of different levels. The WQO, as a small part of the broader Paleotethys Ocean, records 300 m.y. of evolution of the Shang-Dan and Mian-Lue Oceans [14]. The strata of the WQO is dominated by a strongly deformed thick flysch sequence $[14,16]$, which is dominated by Devonian clastic rocks and carbonate rocks with a small amount of Carboniferous and Permian metasedimentary rocks. These rocks were deposited in the Fengtai basin in the Early Palaeozoic and metamorphosed into medium-grade (mainly greenschist) facies in the subsequent orogenic process [17]. Many granitic intrusions are distributed along the sutures and regional faults, forming an approximately EW-trending magmatic belt. Most of these granitoids were emplaced in the Late Triassic [18-20], representing the products of final collision.

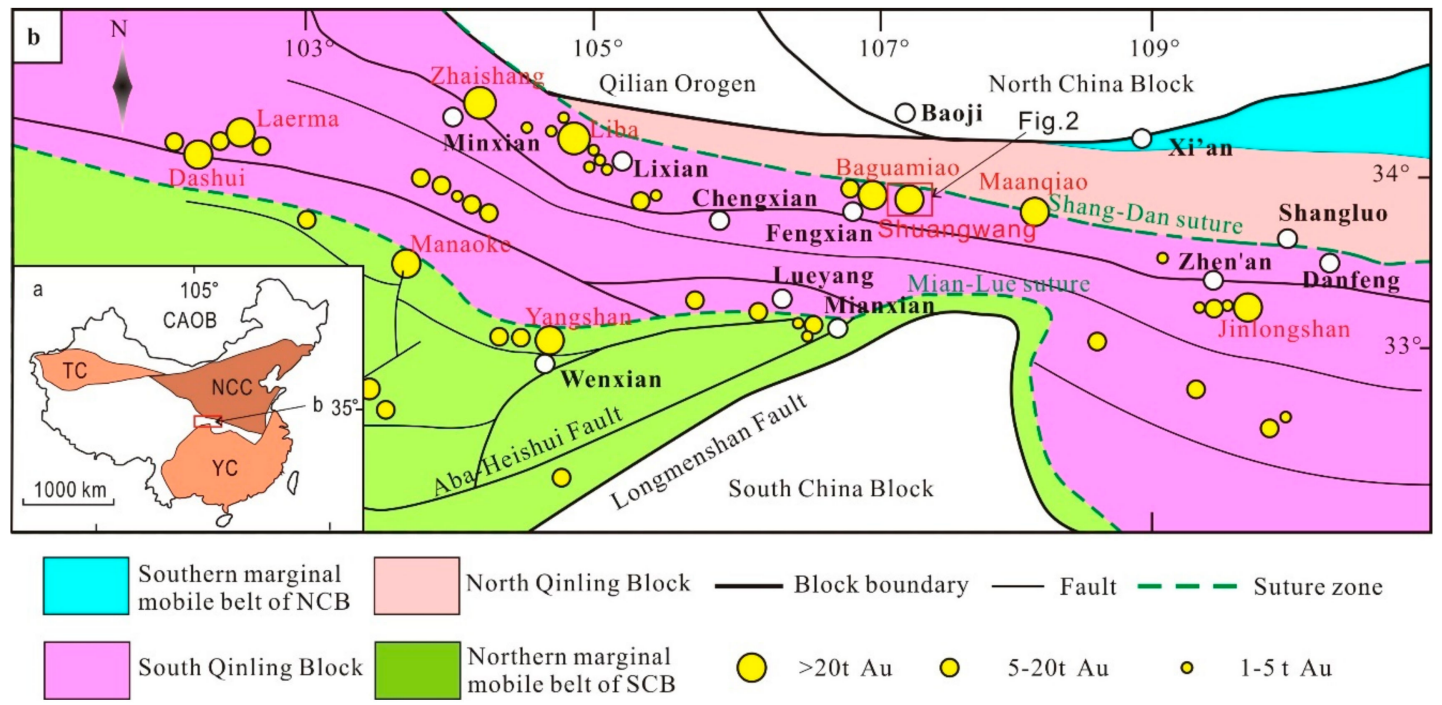

Figure 1. (a) Tectonic division of China. (b) Sketch map of the Western Qinling Orogen (WQO), illustrating major gold deposits and their location (modified after [21]).

There are many gold deposits in the WQO. These gold deposits are the products of Paleozoic orogenic processes between the NCB and the SCB, and have been divided into different genetic types: orogenic, Carlin, and Carlin-like [22-24]. The Carlin (e.g., Jinlongshan, Dashui) and Carlin-like (e.g., Zhaishang, Liba, Yangshan) gold deposits mainly occur in the middle and southern belts of the WQO. They are hosted by weakly metamorphosed Triassic clastic and carbonate rocks [22]. The Carlin-like type differs from the Carlin gold deposit in that they may genetically be related to the synchronous magmatism [24]. The orogenic gold deposits (e.g., Shuangwang, Maanqiao, and Baguamiao), occurring between the two regional sutures, are closely related to WNW-trending shear zones developed in the Paleozoic metasedimentary rocks $[21,23,24]$. These orogenic gold deposits, which were thought to be the result of the early subduction of the Mian-Lue oceanic crust [24], show similar geological geochemical features. Among them, the Shuangwang deposit is characterized by its breccia-type gold ores, and is thus distinct from the other gold deposits in this area. 


\section{Ore-Deposit Geology}

The Shuangwang gold deposit occurred in an NW-extending hydrothermal breccia belt in the Devonian strata of the Fengtai basin, which was described as a forearc basin by previous work [25]. The strata exposed in the Shuangwang gold deposit mainly consist of weakly metamorphosed Devonian clastic rocks and carbonate rocks (Figure 2). The total thickness of the strata is more than $5000 \mathrm{~m}$. The Devonian strata, from old to young, were divided into the Wangjialeng Formation (Lower Devonian), the Gudaoling Formation (Middle Devonian), and the Xinghongpu and Jiuliping Formations (Upper Devonian) [11]. The Wangjialeng Formation is dominated by crystalline limestone and interlaid metamorphosed siltstone and sandy slate. The Gudaoling Formation includes metamorphosed siltstone, crystalline limestone, and biolimestone interlayered with sandstone. The Xinghongpu Formation, which is the ore-hosting stratum, is composed of metamorphosed sandstone and slate (Figure 3a,b). The Jiuliping Formation mainly consists of metasiltstone and slate.

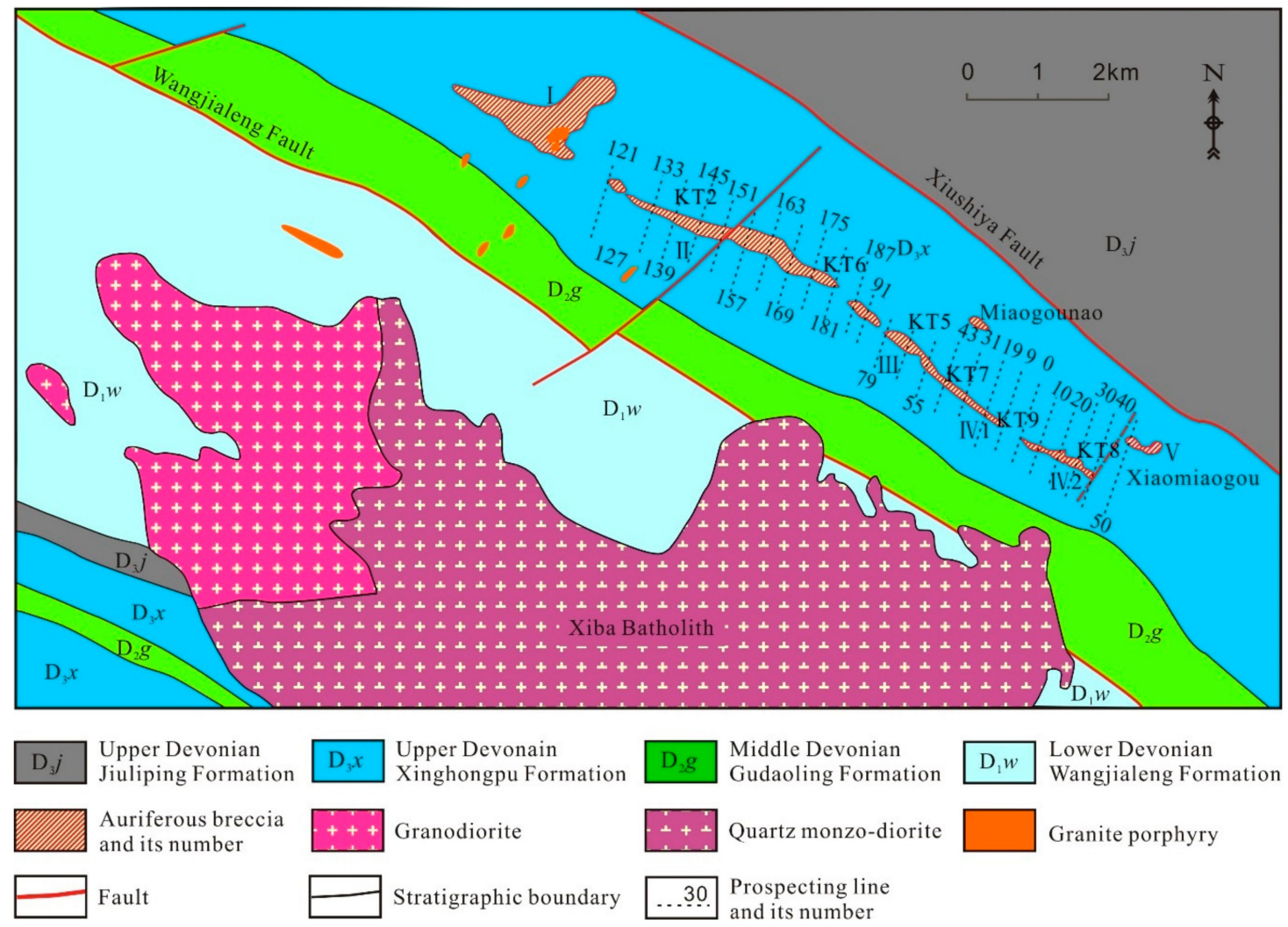

Figure 2. Sketch map of Shuangwang gold deposit (modified after [23]). I-V: number of breccia bodies; KT2-KT9: number of orebodies. See main text for description of the different rock types. The tectonic trend of this area is an NW-SE direction, which is manifested by a series of composite folds and strike-slip faults. The most important fold in the Shuangwang gold district is called the Yindonggou anticline. It is a secondary-order fold structure of the giant Xiba composite anticline [11]. Gold-bearing breccia is hosted in the strata of the northern limb of the Yindonggou anticline. The most striking faults are the NW-trending Wangjialeng and Xiushiya faults (Figure 1). These two faults are parallel to the lithology boundary and confine the occurrence of the gold-bearing breccia (orebody) belt.

Magmatic activity was characterized by Indosinian granitic intrusion in the Shuangwang gold district. The largest intrusion is called the Xiba pluton with an area of about $50 \mathrm{~km}^{2}$ [11]. The Xiba pluton extends in an NWW direction, and is about $1-3 \mathrm{~km}$ south to the gold breccia belt. This pluton intruded into the Devonian stratum along the axis of the Xiba fold. The pluton is mainly composed of quartz monzodiorite (Figure $3 \mathrm{c}$ ) and minor amounts of granodiorite with zircon $\mathrm{U}-\mathrm{Pb}$ ages of ca. 
218-215 Ma [26]. Furthermore, some small Yanshanian granitic porphyries developed in the western part of the Shuangwang gold-bearing breccia belt.
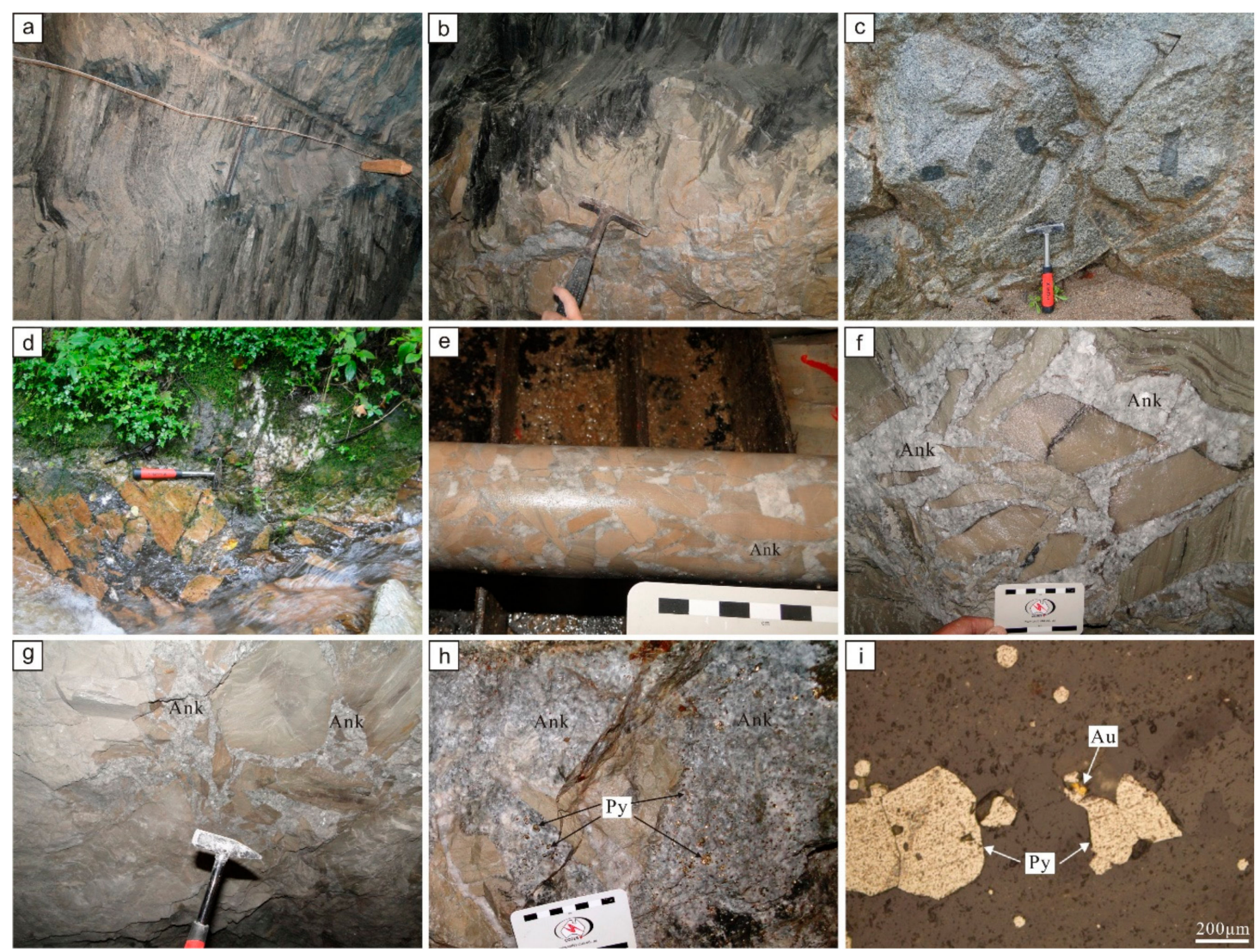

Figure 3. Geology and mineralization features of the Shuangwang gold deposit. (a) Ore-hosting carbonaceous slate of the Xinghongpu Formation (kink bands show strong deformation); (b) bleached albitized slate near the breccia, compared with dark carbonaceous slate; (c) quartz monzodiorite outcrop of the Xiba batholith; (d) outcrop of the Shuangwang gold breccia; (e) gold breccia ores from drill core; (f) fragment of collage, showing no obvious movement of the breccia; (g) angular fragments of different size, showing no sorting and grinding; (h) coarse pyrite in euhedral ankerite; (i) native gold in pyrite. Abbreviations: Ank = ankerite; $\mathrm{Au}=$ gold; $\mathrm{Py}=$ pyrite.

The Shuangwang gold-bearing breccia belt is hosted in the marine sedimentary strata of the Xinghongpu formation. The gold-bearing breccia belt, with a length about $11.5 \mathrm{~km}$ and width about several meters to several hundred meters, extends in an NW direction (290-310 $)$ between the Wangiialeng village and Wangjiazhuang village. The gold-bearing breccia belt is discontinuous on the surface and is named Breccia I-V. Some smaller breccias, such as the Miaogounao and Xiaomiaogou breccias, occur $1 \mathrm{~km}$ further to the north. Along the major breccia belt, a series of orebodies occur, which are named KT8, KT9, KT7, KT5, KT6, and KT2. Among them, orebodies KT8 and KT9 are by far the most important ones, as they account for more than $75 \%$ of the reserve of the Shuangwang gold deposit.

Orebody KT8 is the largest orebody (between prospecting lines 22 and 46), and dips to the NNE at about $75^{\circ}$. KT8 is about $650 \mathrm{~m}$ long with an average thickness of $30 \mathrm{~m}$, extending more than $400 \mathrm{~m}$ at depth (Figure 4). The gold grade of orebody KT8 is higher than that of KT9, averaging $3.08 \mathrm{~g} / \mathrm{t}$. Orebody KT9 is located between prospecting lines 3 and 20. The occurrence of the KT9 is similar to that of the KT8, and it also dips to NNE at a steep angle. It extends for more than $600 \mathrm{~m}$ with thickness of $18 \mathrm{~m}$. The average gold grade of orebody KT9 is $1.98 \mathrm{~g} / \mathrm{t}$. Gold mineralization is better in the upper part than in the lower part of orebodies KT8 and KT9. 
Gold ores are characterized by breccias in the Shuangwang gold deposit. Previous studies showed that gold-bearing breccias are the result of hydraulic fracturing induced by overpressured ore-forming fluid $[10,11,27]$. Breccia ores contain country rock fragments dominated by albitized slate and siltstone (Figure $3 \mathrm{~d}-\mathrm{g}$ ). These fragments vary in diameter, from several millimeters to several meters, and have angular, platy, or irregular shapes, showing no obvious grinding and sorting. Some fragments can be pieced together, indicating very small movement of these fragments (Figure 3f). The size of the fragments is negatively correlated to the gold grade, i.e., the larger the fragments, the lower the gold grade [11]. The mineral composition of the cements includes ankerite, quartz, albite, calcite, and some pyrite [12]. Pyrite is the chief gold-hosting mineral, and gold occurs in native form mainly in interstices between pyrite crystals or in microfractures within pyrite (Figure 3h,i).

Four ore-forming stages have been summarized by previous research [10]. Stage I, replacement stage before brecciation with an ankerite-quartz-albite assemblage; Stage II is represented by an assemblage of quartz, albite, pyrite, and ankerite; Stage III has a pyrite-calcite-quartz assemblage; Stage IV exhibits an assemblage of fluorite, dickite, and gypsum with no gold deposition. Stage II is the major gold deposition stage in the Shuangwang gold deposit.

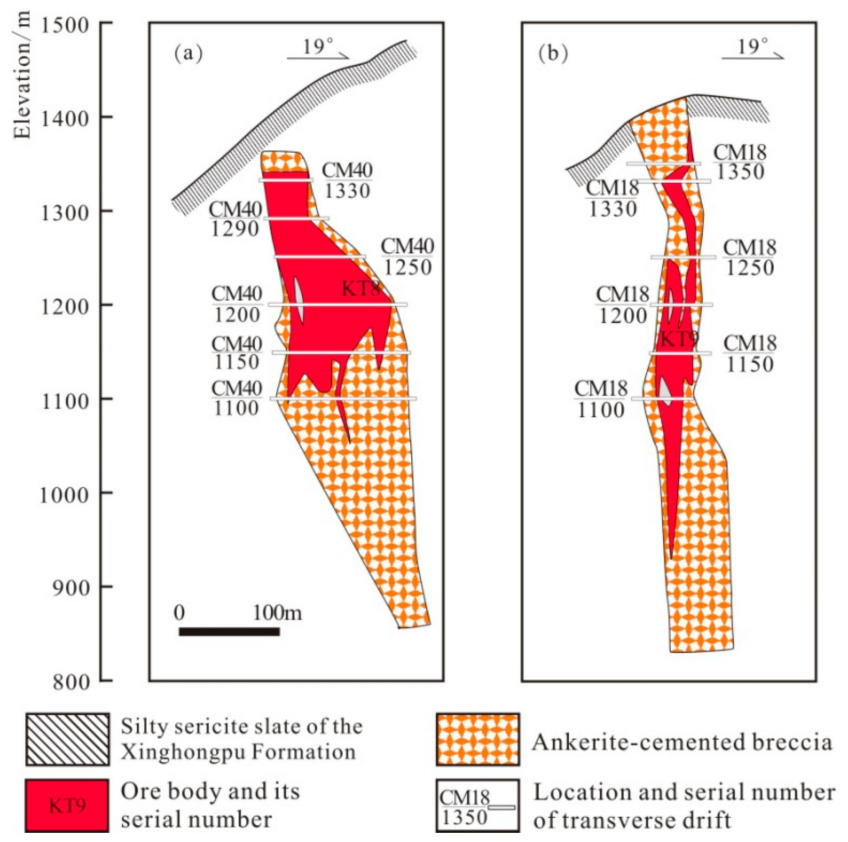

Figure 4. Cross sections of prospecting line 40 of the KT8 (a) and line 18 of the KT9 (b) from the Shuangwang deposit, showing the occurrence of breccia bodies and the orebodies.

\section{Sampling and Analytical Methods}

Fifty-eight ore samples from the major ore-forming-stage ores were collected from most accessible drifts at levels 1100, 1150, 1200, 1250, and 1330 of orebodies KT8 and KT9 (1100 is the lowest operating level).

Samples were firstly crushed into 40-60 mesh grains. After panning and filtration, pyrite crystals with $>99 \%$ purity were handpicked under microscope. The morphologic study of pyrite crystals was carried out under a binocular microscope at the State Key Laboratory of Geological Processes and Mineral Resources, China University of Geosciences (Beijing, China) (CUGB).

Thermoelectricity of the pyrite samples was tested by a BHTE-06 thermoelectric coefficient measuring instrument at the Genetic Mineralogy Laboratory of CUGB. The temperature of the cold end and the hot end was set to 20 and $80^{\circ} \mathrm{C}$, respectively. Fifty pyrite grains were randomly selected from each sample for measurements. 
Trace elements of pyrites were tested by high-resolution inductively coupled plasma mass spectrometry (HR-ICP-MS) Element I in the analytical laboratory center of the Beijing Research Institute of Uranium Geology (BRIUG) following the national standard of DZ/T0223-2001 [28]. About $50 \mathrm{mg}$ of powered pyrite was dissolved in high-pressure Teflon bombs using an $\mathrm{HF}+\mathrm{HNO}_{3}$ mixture. The signal collection of HR-ICP-MS lasted $25 \mathrm{~s}$, and the scanned mass ranges were set at 6-235 amu to cover target elements. The experimental processes were conducted under a temperature of $20{ }^{\circ} \mathrm{C}$ and relative humidity of $30 \%$. The uncertainties of the ICP-MS analyses were estimated to be better than $\pm 5 \%$. According to previous research [29], indicator elements such as $\mathrm{Ba}, \mathrm{Sb}$ (supraore halo elements), $\mathrm{Pb}$, $\mathrm{Zn}, \mathrm{Cu}$ (near-ore halo elements), and Co, Mo, Bi (subore halo elements) were chosen to analyze their special distribution for deep ore prediction in the Shuangwang gold deposit.

\section{Analytical Results}

\subsection{Crystal Habits}

Pyrite crystal morphology is affected by many factors, such as chemical compositions, inner structure, and geological environment. Thus, it bears important genetic and prospecting information [30]. Generally, pyrites from the early ore-forming stage are cube or pentagonal dodecahedron coarse $(>1 \mathrm{~mm}) \mathrm{crystal}$ and poor in gold, whereas pyrites from the main ore-forming stage are dominated by combinative form fine $(<1 \mathrm{~mm}$ ) crystal rich in gold. Pyrite crystal morphology of the Shuangwang gold deposit is relatively simple. The major crystal habits of pyrite include $\{100\},\{111\}$, and $\{210\}$ (Figure 5), accounting for $41.5 \%$, $31.3 \%$, and $27.2 \%$, respectively (Table A1).



Figure 5. Crystal forms of pyrites from Shuangwang gold deposit. (a) Cubic crystal (with striations); (b) combinative form of cubic and octahedron; (c) octahedron crystal; (d) combinative form of octahedron and pyritohedron; (e) pyritohedron crystal; (f) pyritohedron and cubic combinative form.

\subsection{Thermoelectricity}

Generally, pyrite thermoelectricity deals with two related aspects, namely, thermoelectric coefficient and conductivity type. The pyrite thermoelectric coefficient can be directly tested through a thermoelectric measuring instrument. Two types of conductivity for pyrite, that is, electron conduction (N-type) and hole conduction (P-type) are divided according to the value of the thermoelectric coefficient. N-type refers to pyrite with a negative thermoelectric coefficient value, and P-type refers to pyrite with a positive thermoelectric coefficient value $[30,31]$. A previous study showed that P-type 
pyrite is positive to gold mineralization, in other words, gold mineralization is strong where P-type pyrite is dominant $[8,9,32,33]$.

A total of 3100 pyrite grains were tested for the thermoelectric coefficients (26 samples from orebody KT8, and 36 samples from the orebody KT9, 50 analyses for each sample). Pyrite thermoelectric coefficients of orebody KT8 ranged from -269.58 to $200.65 \mu \mathrm{V} /{ }^{\circ} \mathrm{C}$. N-type pyrite accounted for $67.8 \%$ with an average thermoelectric coefficient value of $-152.58 \mu \mathrm{V} /{ }^{\circ} \mathrm{C}$. P-type pyrite accounted for $32.2 \%$, and the average thermoelectric coefficient value was $127.36 \mu \mathrm{V} /{ }^{\circ} \mathrm{C}$. Pyrite thermoelectric coefficients of orebody KT9 had a range of $-187.89 \sim 216.73 \mu \mathrm{V} /{ }^{\circ} \mathrm{C}$. N-type pyrite accounted for $51.06 \%$, with an average thermoelectric coefficient value of $-133.34 \mu \mathrm{V} /{ }^{\circ} \mathrm{C}$. P-type pyrite accounted for $48.94 \%$, and the average thermoelectric coefficient value was $146.96 \mu \mathrm{V} /{ }^{\circ} \mathrm{C}$ (Table A2).

\subsection{Chemical Composition}

Contents of eight kinds of indicator elements are presented in Tables A3 and A4. The values of supraore halo elements $\mathrm{Ba}$ and $\mathrm{Sb}$ ha relatively small ranges of $0.5-10.0 \mu \mathrm{g} / \mathrm{g}$ and $0.4-6.7 \mu \mathrm{g} / \mathrm{g}$ (excluding an anomalously high value of 22.4), with average values of 2 and $2.3 \mu \mathrm{g} / \mathrm{g}$, respectively. The values of near-ore halo elements $\mathrm{Pb}, \mathrm{Zn}$, and $\mathrm{Cu}$ averaged at $14.4,14.2$, and $46.8 \mu \mathrm{g} / \mathrm{g}$, respectively, ranging from 1.2 to $66.6 \mu \mathrm{g} / \mathrm{g}$ (excluding three anomalously high values of 117, 385, and 590), 9.1 to $39 \mu \mathrm{g} / \mathrm{g}$, and 34 to $94 \mu \mathrm{g} / \mathrm{g}$ (excluding two anomalously high values of 172 and 251). The values of subore halo elements $\mathrm{Co}$, Mo, and Bi varied from 25 to $808 \mu \mathrm{g} / \mathrm{g}$ (excluding an anomalously high value of 2103 ), 0.1 to $2.9 \mu \mathrm{g} / \mathrm{g}$ (excluding three anomalously high values of 9.3,11.7, and 25.8), and 0.1 to $13 \mu \mathrm{g} / \mathrm{g}$, with average values of $212,0.58$, and $3.2 \mu \mathrm{g} / \mathrm{g}$.

\section{Distribution of Typomorphic Pyrite Factors}

\subsection{Distribution of Pyrite Crystal Habits}

The characteristics of pyrite crystals vary with their formation process under different physicochemical conditions. Generally, during the main mineralization stage, when ore-forming temperature is moderate and sulphur fugacity is high, pyrite with $\{210\},\{210\}+\{100\}$, and other combinative forms is dominant. A general sequence of forms indicating an increasing degree of supersaturation is cube to octahedron to pyritohedron. Mapping of pyrite habit could delineate zones of the high supersaturation of hydrothermal fluids and zones of potential mineralization [34]. Thus, we can predict the deep orebody by variation of pyrite crystal forms.

According to the research of the Jinqingding gold deposit in Jiaodong, China, Li [35] put forward the morphology index of pyrite and successfully applied this index in mapping to predict deep orebodies. The morphology index of our study was calculated according to the following formula:

$$
X=C_{\{100\}} \times(-1)+C_{\{111\}} \times 0+C_{\{h k 0\}} \times 1
$$

$\mathrm{C}_{\{100\}}, \mathrm{C}_{\{111\}}$, and $\mathrm{C}_{\{h k 0\}}$ are the percentages of pyrite with $\{100\},\{111\},\{h k 0\}$ habits, respectively. Usually, a high morphology index indicates strong gold mineralization. We obtained the contour map of the pyrite morphology index by using surfer software. The general trend of pyrite morphology index is high in the shallow levels and low in the deep levels, especially for KT8. This is consistent with gold-grade distribution. A very large positive anomaly occurs between prospecting lines 12 and 48 , with a strong positive value centered at level 1150 on prospecting line 16 . This is in accordance with the fact that gold mineralization is better in KT8 than in KT9. There are three anomalies at level 1100, e.g., on prospecting line 26 and 30, and between prospecting lines 44 and 46 (Figure 6). These anomalies show a clear deep extending trend, indicating possible gold mineralization at depth. 


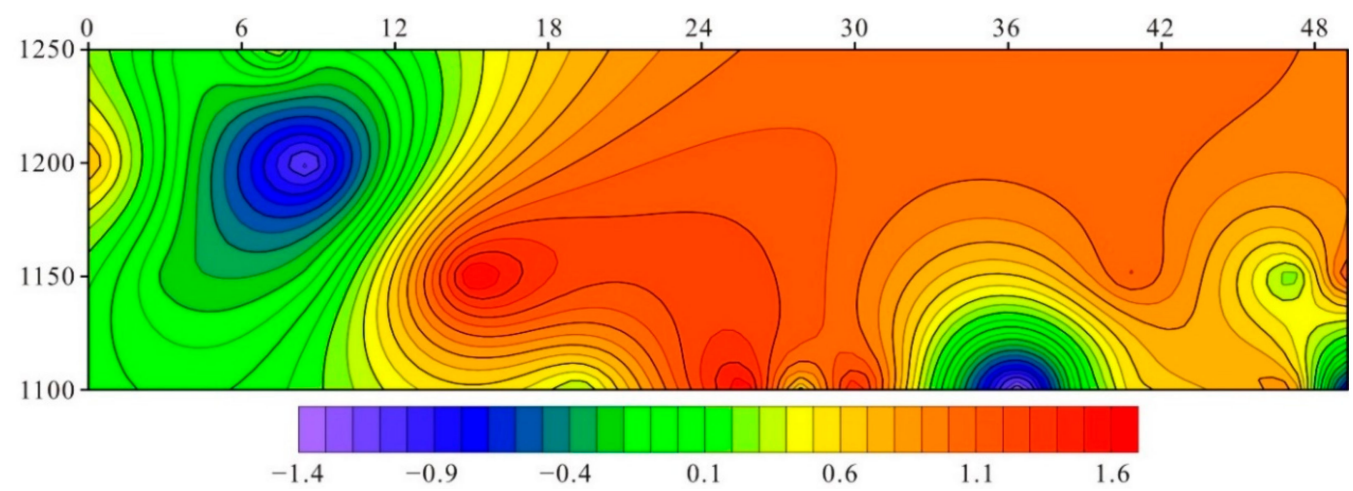

Figure 6. Contour map of crystal index of pyrites from orebodies KT8 and KT9 of the Shuangwang gold deposit. $X$ axis is prospecting line and $Y$ axis is elevation $(m)$. $X$ and $Y$ axes are the same as Figure 6 in the following figures.

\subsection{Distribution of Pyrite Thermoelectric Coefficient}

The P-type frequency contour map of orebody KT8 shows high values in the central area. There occurs one large positive anomaly, i.e., level 1100 of prospecting line 32. This anomaly shows an obvious deep extending trend. The P-type frequency contour map of orebody KT9 shows two clear positive anomalies in the shallow area and a downward decrease. These two anomalies close above level 1150, but the right one pinches out and reappears at level 1100 along prospecting line 18, indicating a possible extension of gold orebody at depth (Figure 7).

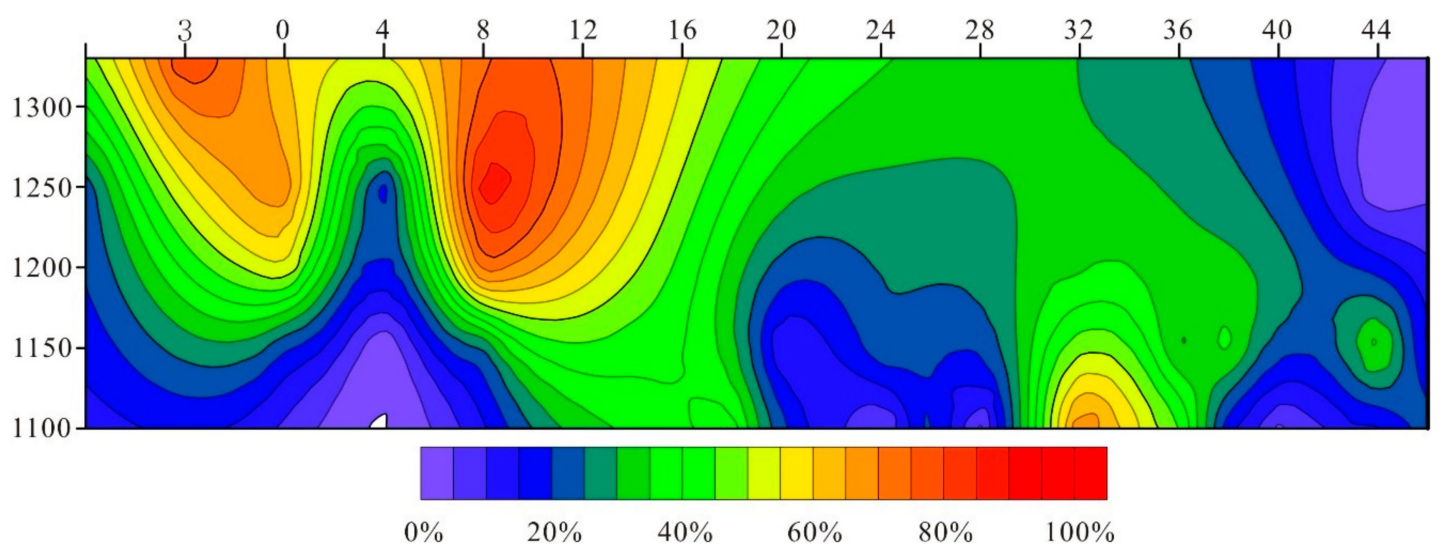

Figure 7. Contour map of P-type frequency of pyrites from orebodies KT8 and KT9 of the Shuangwang gold deposit.

\subsection{Distribution of Pyrite Chemical Composition}

Supraore halo element Ba is richer in KT8 than in KT9. Only a small high-value anomaly occurs at level 1200 along prospecting line 0 (Figure 8). There are three anomalies in KT8, i.e., at level 1150 of prospecting line 24, at level 1100 between prospecting lines 30 and 32, and along prospecting line 36. The latter two anomalies show a deep extension trend. $\mathrm{Sb}$ is concentrated in the area west from prospecting line 0 , indicating that KT9 may extend deep to the west. There occur two Sb anomalies in KT8, an enclosed one at level 1150 of prospecting line 36 and a deep-extending one at level 1100 between prospecting lines 26 and 28 .

Contents of near-ore halo elements are higher at depth than at the shallow level (Figure 9). For the $\mathrm{Pb}$ contour map, there were four unclosed anomalies at level 1100 along prospecting line $8,28,36$, and 42. As for the Zn contour map, there developed five unclosed anomalies at level 1100 along lines 3, 12, 24,28 , and 36. These unclosed anomalies may indicate gold mineralization at depth. $\mathrm{Cu}$ anomalies 
occurred west of prospecting line 3 and between prospecting line 36 and 40 . The east one closed above level 1100, while the western anomaly shows a deep extension trend.

Subore halo elements Co, Mo, and Bi increased from shallow to deep, especially for KT8 (Figure 10). Subore halo elements coexist with supraore elements at level 1100 at prospecting lines 28, 32, and 36, indicating concealed orebodies at depth. The high value of Co between prospecting lines 7 and 10 shows that gold mineralization of KT9 may not be very well at depth. Co shows an obvious increasing trend downward between prospecting lines 14 and 20, indicating the possibility of gold mineralization at depth.

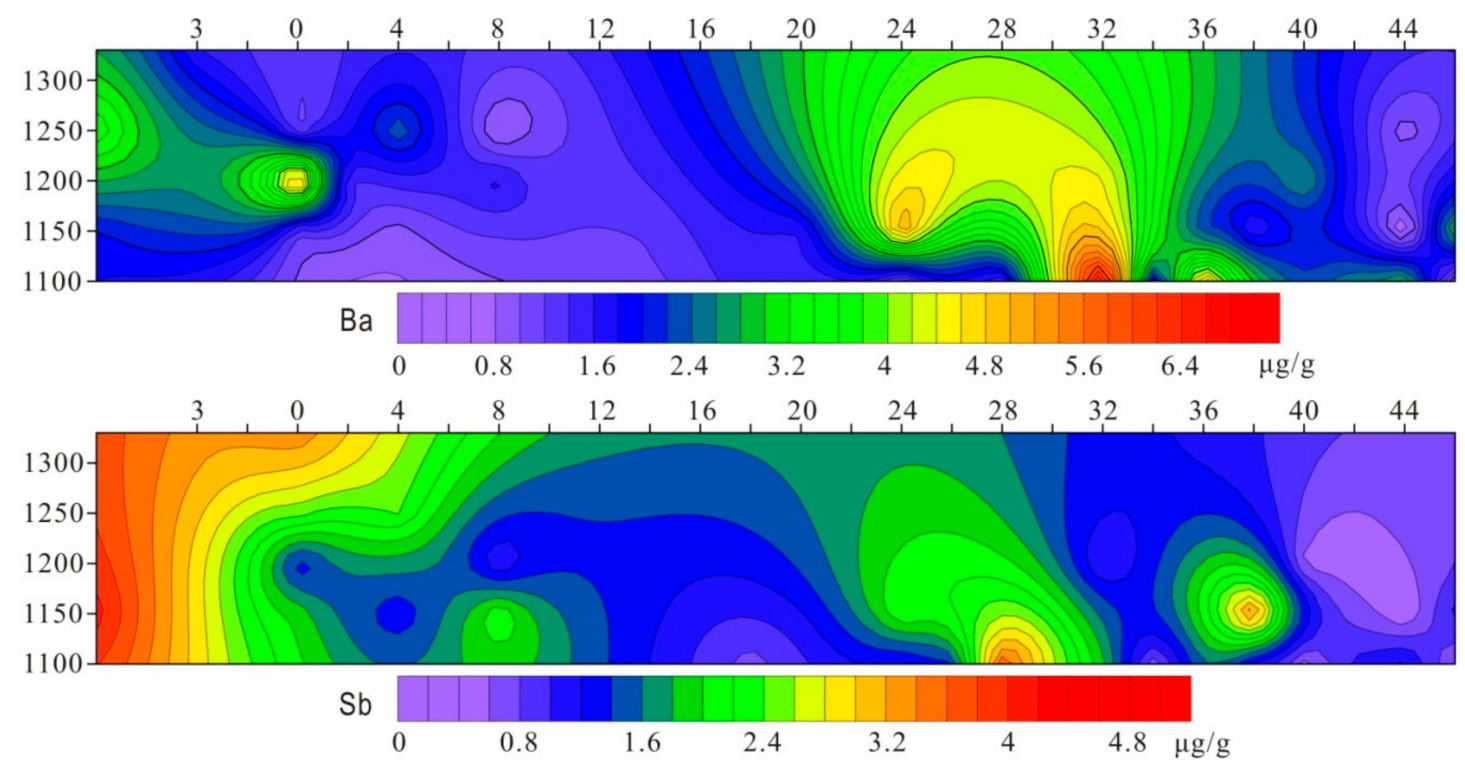

Figure 8. Distribution of supraore halo elements Ba and Sb of orebodies KT8 and KT9.

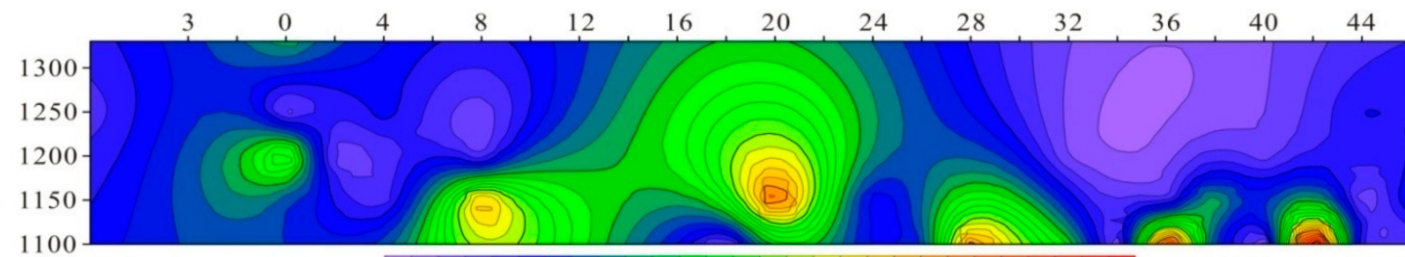

$\mathrm{Pb}$
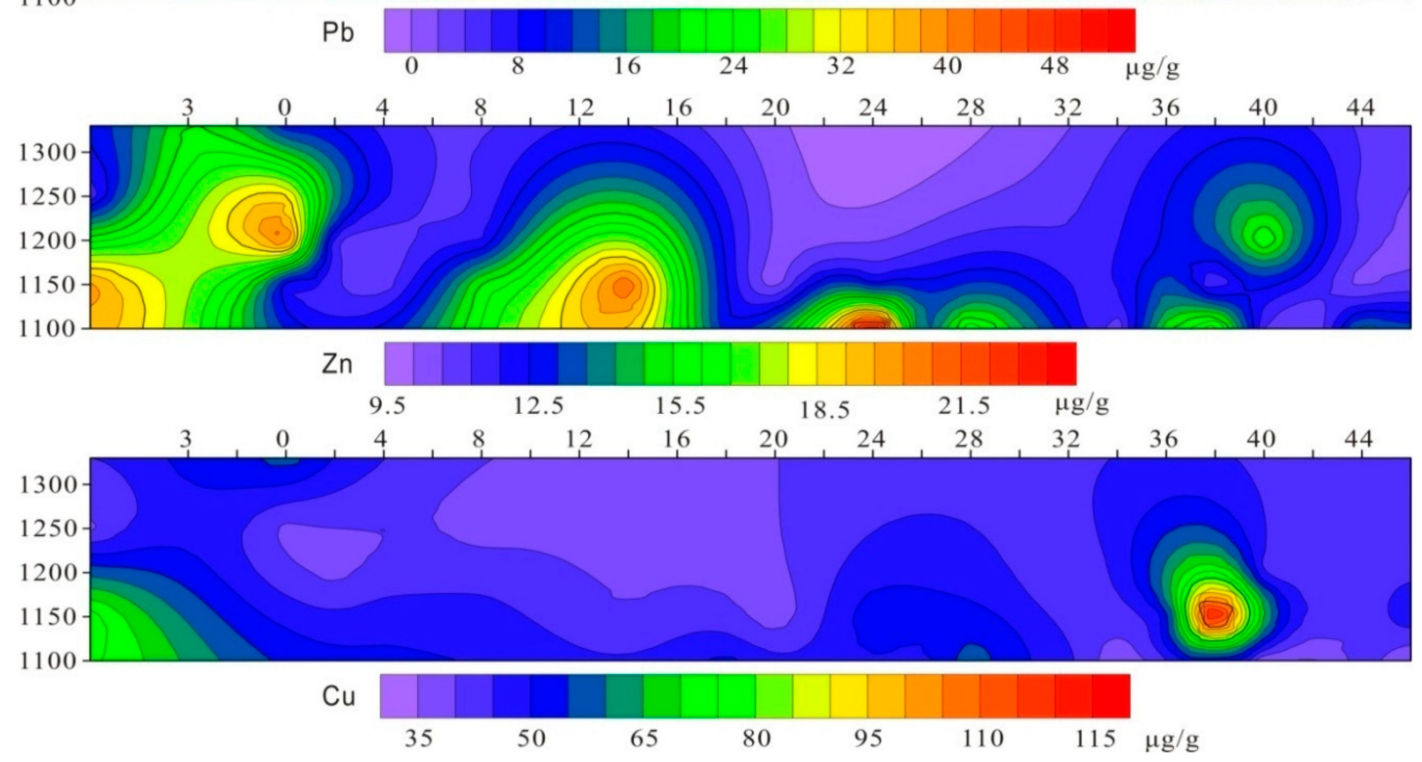

Figure 9. Distribution of near-ore halo elements $\mathrm{Pb}, \mathrm{Zn}, \mathrm{Cu}$ of orebodies KT8 and KT9. 

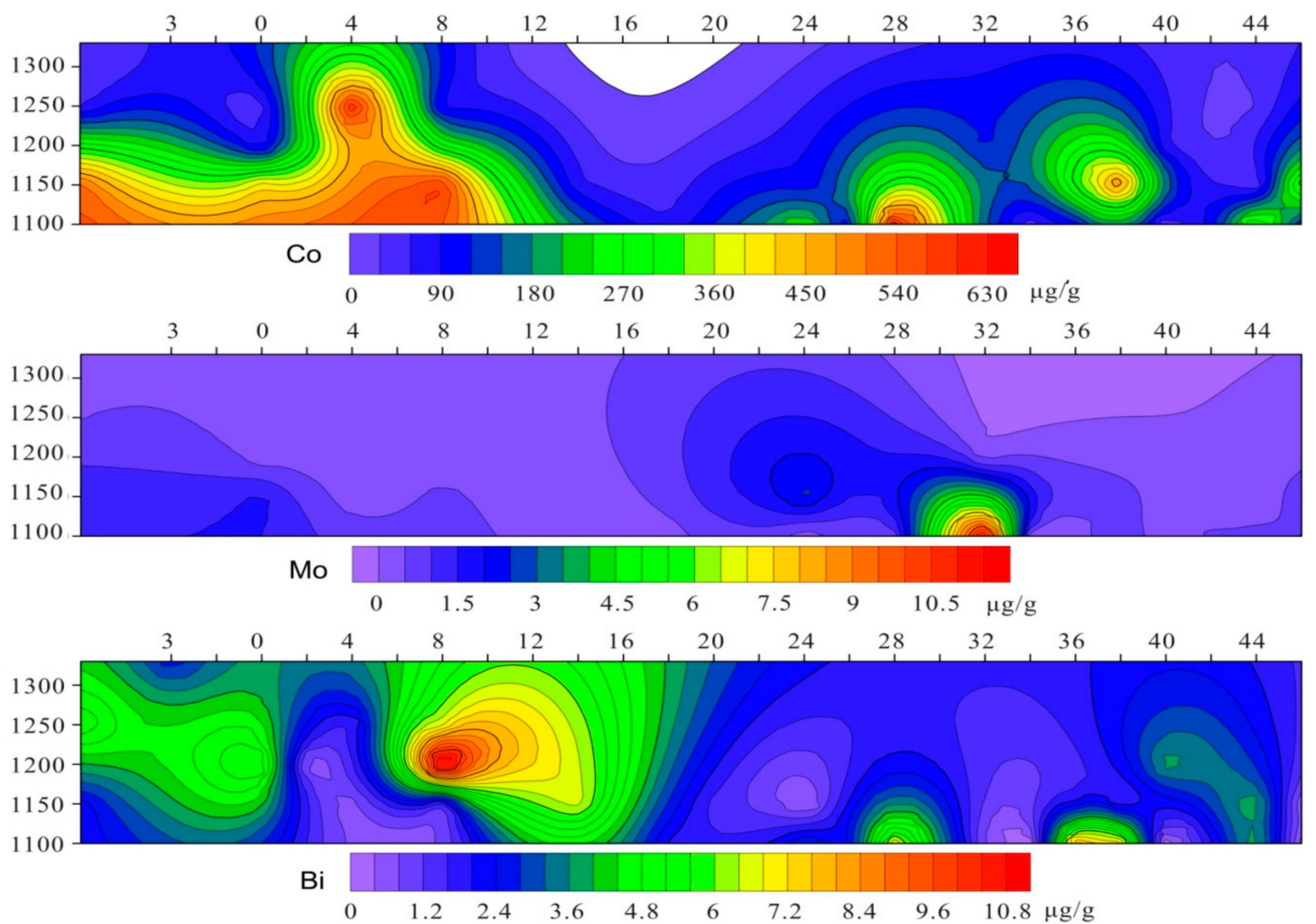

Figure 10. Distribution of subore halo elements $\mathrm{Co}$, Mo, Bi of orebodies KT8 and KT9.

\section{Deep Ore Prediction}

According to the comprehensive analysis of the contour maps of morphology index, P-type frequency, and indicator elements, some target areas that show at least two kinds indicating information about the morphology, thermoelectricity, and chemical composition of pyrite were delineated for future gold exploration at depth (Figure 11).

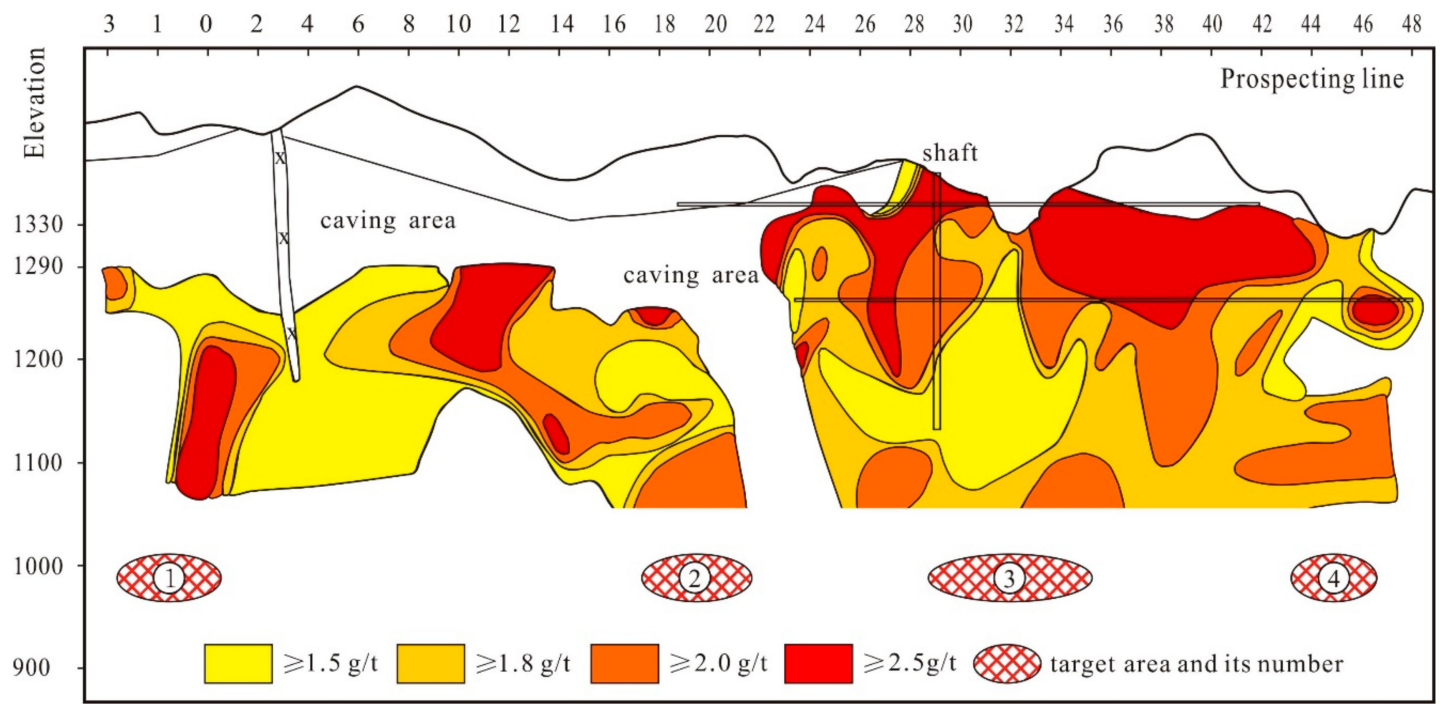

Figure 11. Gold prediction at depth and vertical longitudinal projection of orebodies KT8 and KT9 of the Shuangwang gold deposit. 
Target (1): The area between prospecting lines 0 and 1 showed weak anomaly of morphology index. Supraore element $\mathrm{Sb}$ and near-ore elements $\mathrm{Zn}$ and $\mathrm{Cu}$ had clear anomalies. There were no P-type frequency anomalies in this area.

Target (2): Anomalies of P-type frequency and an intense $\mathrm{Zn}$ anomaly between prospecting lines 14 and 18 indicated possible mineralization at depth, but this target showed no morphology index anomalies.

Target (3): The area between prospecting lines 30 and 34 where anomalies of morphology index and P-type frequency showed clear deep extension. The high contents of supraore halo elements Ba and $\mathrm{Sb}$, together with subore halo element anomalies, pointed to the possibility of downward extension of the orebody, or of a concealed orebody.

Target (4): The area between prospecting lines 44 and 46 showed a deep extension morphology index anomaly, together with weak anomalies of $\mathrm{Ba}, \mathrm{Bi}$, and $\mathrm{Co}$. There were no P-type frequency anomalies in this area.

The four target areas above are substantiated with deep extension of proven orebodies (Figure 11). There occurred chemical anomalies in all the four targets, whereas morphology anomalies were absent in Target (2), and thermoelectricity anomalies were missing in Targets (1) and (4). Among these four targets, the third is the most prospective area with strong information from morphology index, P-type frequency, and halo elements. More attention should be paid to these four target areas in future gold exploration at depth, and especially the third target.

\section{Concluding Remarks}

Pyrite typomorphic features of different gold deposits have been studied in detail since the 1970s, especially in China and the former Soviet Union, not only for the genesis of gold deposits but also for gold exploration. The present pyrite typomorphic research delineated four prospective targets at the depth of orebodies KT8 and KT9 of the Shuangwang gold deposit. These targets are in agreement with the deep extension of known gold mineralization, indicating that pyrite typomorphic study is an effective way to deep gold predict orogenic gold deposits or other gold deposits of hydrothermal origin.

Indications of the crystal habit, thermoelectricity, and chemical composition of pyrite for deep gold prediction are different. The role of chemical composition is direct and obvious. Information for deep ore prediction from the crystal habit and thermoelectricity of pyrite is indirect and sometimes ambiguous, because these two parameters are affected by many factors. Considering the easy and cheap data-acquired method for crystal habit and thermoelectricity, a comprehensive study on the pyrite typomorphism of morphology, thermoelectricity, and chemical composition is suggested in order to acquire as much information as possible.

Author Contributions: Conceptualization, J.W.; data curation, Z.L. and K.W.; funding acquisition, J.W.; investigation, Z.L., K.W., X.Z., and F.Z.; methodology, Z.L.; software, X.Z.; supervision, J.L.; visualization, K.W.; writing—original draft, J.W.; writing—review and editing, J.L. and F.Z.

Funding: This study was funded by the National Natural Science Foundation of China (No. 41730426, 41272106, 41030423).

Acknowledgments: The authors thank Li Hongbin and Cao Ruirong of the Shuangwang Gold Mine for the pleasant cooperation. We also thank Cheng Jianjun, Wang Lo, and Qi Feng for their help during the fieldwork. The three anonymous reviewers are gratefully appreciated for suggestive comments on the manuscript.

Conflicts of Interest: The authors declare no conflict of interest. 


\section{Appendix A}

Table A1. Crystal habit of pyrites from orebodies KT8 and KT9.

\begin{tabular}{|c|c|c|c|c|c|c|c|c|c|c|c|c|c|}
\hline \multirow{2}{*}{ Level (m) } & \multirow{2}{*}{ Sample No. } & \multicolumn{4}{|c|}{100} Habit & \multicolumn{4}{|c|}{111} Habit & \multicolumn{4}{|c|}{ hk0\} Habit } \\
\hline & & $\{100\}$ & $\{111\}$ & $\{h k 0\}$ & com & $\{111\}$ & $\{100\}$ & $\{h k 0\}$ & com & $\{h k 0\}$ & $\{100\}$ & $\{111\}$ & com \\
\hline \multirow{6}{*}{1150} & $3-46-1$ & & 1 & & & 5 & 8 & 17 & & 1 & 3 & 13 & 3 \\
\hline & 3СМ36-2 & 6 & 6 & 2 & 3 & & & & & 7 & 15 & 4 & 7 \\
\hline & 3СМ36-3 & & & & & 11 & 1 & 22 & & 4 & 5 & 5 & 2 \\
\hline & 3СМ36-5 & 10 & 5 & & & 11 & 5 & 6 & & 4 & 2 & 7 & \\
\hline & 3СМ38-6 & & & & & 6 & 9 & 6 & 1 & 1 & 1 & 5 & 6 \\
\hline & 3СM44-6 & & 1 & & & 3 & 26 & 14 & 2 & 2 & 1 & & 1 \\
\hline \multirow{17}{*}{1100} & 4CM24-2 & & 11 & 1 & & 1 & 2 & & & 7 & 16 & 5 & 7 \\
\hline & 4CM26-3 & 9 & 9 & 1 & 2 & 2 & & 4 & & 4 & 12 & 6 & 1 \\
\hline & 4CM28-4 & 7 & 3 & & & 1 & 5 & 3 & & 6 & 20 & 1 & 4 \\
\hline & 4CM34-2 & 3 & 43 & & & 1 & 3 & & & & & & \\
\hline & 4CM36-4 & & 1 & & & 5 & 12 & 7 & 2 & 3 & 7 & 7 & 6 \\
\hline & 4CM36-5 & & 12 & 1 & & 1 & 31 & 1 & & 1 & 1 & 3 & 1 \\
\hline & 4CM36-6 & 28 & 12 & 6 & & & 1 & & & 1 & 1 & 1 & \\
\hline & 4CM36-8 & & 1 & & & 25 & 16 & 6 & & & 1 & 1 & \\
\hline & 4CM38-5 & & 1 & & 1 & 9 & 1 & 29 & & 3 & & 6 & \\
\hline & 4CM38-6 & & 3 & & & 6 & 9 & 17 & & & 4 & 9 & 2 \\
\hline & 4CM38-7 & & 1 & & & 8 & 4 & 31 & & & 1 & 6 & \\
\hline & 4CM44-5 & 1 & 4 & & & 9 & 11 & 4 & & 1 & 7 & 11 & 2 \\
\hline & 4CM44-6 & & 1 & & & 17 & 3 & 15 & 3 & 1 & & 7 & 4 \\
\hline & $1100 \mathrm{CM} 32-1$ & 25 & 21 & 4 & & & & & & & & & \\
\hline & 1100CM34-1 & & 28 & & & 1 & 17 & & & 2 & & 2 & \\
\hline & 1100CM46-1 & 8 & 27 & & & 2 & 7 & & & 1 & 3 & 1 & 1 \\
\hline & 1100CM46-2 & 20 & 18 & & & 1 & 1 & 2 & & 1 & 6 & 3 & 3 \\
\hline 1330 & 1330СM0-1 & & & & & 23 & 5 & 16 & & 1 & & 5 & \\
\hline \multirow{3}{*}{1250} & 1CM4-5 & 16 & 4 & 2 & & 7 & 5 & 5 & & 1 & 4 & 4 & 2 \\
\hline & 1CM7-1 & 4 & 13 & & & 5 & 12 & & & 2 & 6 & 7 & 2 \\
\hline & 1CM8-1 & 3 & 3 & & & 22 & 16 & 4 & & & & 2 & \\
\hline \multirow{3}{*}{1200} & $2-3-20-1$ & 11 & 20 & 1 & & & 1 & & & 4 & 9 & 2 & 2 \\
\hline & 2CM0-1 & & 13 & & & 13 & 17 & 1 & & 1 & 2 & & 3 \\
\hline & 2CM0-3 & & 3 & & & 3 & 1 & 13 & 1 & 1 & 2 & 22 & 4 \\
\hline \multirow{5}{*}{1150} & 3СМ0-2 & & 1 & & & 4 & 2 & & & 1 & 1 & 1 & \\
\hline & 3CM14-1 & & 1 & 1 & & 5 & 6 & 4 & & 16 & 16 & 1 & \\
\hline & 3СM14-3 & & 2 & & 1 & 3 & 11 & 3 & 1 & 3 & 18 & & 8 \\
\hline & 3СM14-4 & 1 & 5 & & & 3 & 8 & 5 & & & 4 & 18 & 6 \\
\hline & 3СM8-3 & 5 & 13 & 1 & & 5 & 9 & 6 & 1 & & 5 & 1 & 4 \\
\hline \multirow{2}{*}{1100} & 4CM18-2 & & 11 & 1 & & 9 & 17 & 5 & & & 1 & 4 & 2 \\
\hline & 4CM18-3 & 2 & 18 & & 1 & 2 & 2 & 1 & & 2 & 19 & & 3 \\
\hline Sum & & 228 & 451 & 35 & 13 & 293 & 448 & 337 & 30 & 169 & 252 & 318 & 97 \\
\hline
\end{tabular}

Note: com, combinative form. Samples above 1330CM0-1 are from KT8 and below (included) are from KT9.

Table A2. Thermoelectric properties of pyrite from orebodies KT8 and KT9.

\begin{tabular}{|c|c|c|c|c|c|c|}
\hline \multirow{2}{*}{ Sample No. } & \multirow[t]{2}{*}{ Level (m) } & \multicolumn{2}{|c|}{$\begin{array}{c}\text { N-Type Thermoelectricity } \\
\alpha /\left(\mu \mathrm{V} /{ }^{\circ} \mathrm{C}\right)\end{array}$} & \multicolumn{2}{|c|}{$\begin{array}{l}\text { P-Type Thermoelectricity } \\
\qquad \alpha /\left(\mu \mathrm{V} /{ }^{\circ} \mathrm{C}\right)\end{array}$} & \multirow{2}{*}{$\begin{array}{c}\text { Thermoelectric } \\
\text { Parameter }\end{array}$} \\
\hline & & Average & N (\%) & Average & P (\%) & \\
\hline 1CM44-1 & 1250 & -269.58 & 100 & - & - & -198 \\
\hline $2-3-24-1$ & 1200 & -115.15 & 76 & 110.1 & 24 & -78 \\
\hline $2-3-38-2$ & 1200 & -34.93 & 8 & 151.13 & 92 & 24 \\
\hline $2-4-40-1$ & 1200 & -248.59 & 96 & 113.5 & 4 & -178 \\
\hline 2CM32-4 & 1200 & -113.54 & 66 & 108.71 & 34 & -72 \\
\hline 2CM40-1 & 1200 & -209.2 & 72 & 131.67 & 28 & -110 \\
\hline $3-46-1$ & 1150 & -146.36 & 86 & 140.6 & 14 & -100 \\
\hline 3СМ36-2 & 1150 & -159.31 & 62 & 177.42 & 38 & -60 \\
\hline 3СМ36-3 & 1150 & -109.1 & 80 & 100.71 & 20 & -84 \\
\hline 3СМ36-5 & 1150 & -143.08 & 70 & 124.38 & 30 & -80 \\
\hline 3СМ38-1 & 1150 & -116.21 & 42 & 162.64 & 58 & -32 \\
\hline
\end{tabular}


Table A2. Cont.

\begin{tabular}{|c|c|c|c|c|c|c|}
\hline \multirow[t]{2}{*}{ Sample No. } & \multirow[t]{2}{*}{ Level (m) } & \multicolumn{2}{|c|}{$\begin{array}{c}\text { N-Type Thermoelectricity } \\
\alpha /\left(\mu \mathrm{V} /{ }^{\circ} \mathrm{C}\right)\end{array}$} & \multicolumn{2}{|c|}{$\begin{array}{c}\text { P-Type Thermoelectricity } \\
\alpha /\left(\mu \mathrm{V} /{ }^{\circ} \mathrm{C}\right)\end{array}$} & \multirow{2}{*}{$\begin{array}{c}\text { Thermoelectric } \\
\text { Parameter }\end{array}$} \\
\hline & & Average & N (\%) & Average & P (\%) & \\
\hline 3СМ38-4 & 1150 & -142.92 & 100 & - & - & -114 \\
\hline 3СМ38-5 & 1150 & -85.39 & 80 & 165.94 & 20 & -72 \\
\hline 3СM38-6-E & 1150 & -81.75 & 56 & 112.55 & 44 & -50 \\
\hline 3CM38-6-L & 1150 & -169.72 & 90 & 164.74 & 10 & -114 \\
\hline 3СM44-6 & 1150 & -147.53 & 62 & 147.71 & 38 & -64 \\
\hline 1100СМ32-1 & 1100 & -121.19 & 30 & 200.65 & 70 & 8 \\
\hline 1100CM34-1 & 1100 & -134.38 & 66 & 111.95 & 34 & -72 \\
\hline 1100CM42-1 & 1100 & -228.61 & 90 & 197.72 & 10 & -142 \\
\hline 1100СM44-1 & 1100 & -165.68 & 80 & 149.65 & 20 & -102 \\
\hline 1100CM46-1 & 1100 & -159.08 & 80 & 108.01 & 20 & -104 \\
\hline 1100СМ46-2 & 1100 & -163.93 & 76 & 131.66 & 24 & -94 \\
\hline 4CM24-2 & 1100 & -158.74 & 96 & 158.85 & 4 & -110 \\
\hline 4CM26-3 & 1100 & -170.24 & 78 & 94.62 & 22 & -104 \\
\hline 4CM28-4 & 1100 & -113.46 & 96 & 106.4 & 4 & -106 \\
\hline 4CM34-2 & 1100 & -98.12 & 18 & 169.88 & 82 & 12 \\
\hline 4CM36-4 & 1100 & -148.26 & 74 & 145.41 & 26 & -84 \\
\hline 4СM36-5 & 1100 & -134.83 & 80 & 65.13 & 20 & -94 \\
\hline 4СМ36-6 & 1100 & -156.85 & 28 & 169.02 & 72 & -8 \\
\hline 4CM36-8 & 1100 & -125.37 & 34 & 153.69 & 66 & -18 \\
\hline 4CM38-2 & 1100 & -204.15 & 100 & - & - & -136 \\
\hline 4CM38-5 & 1100 & -166.33 & 80 & 177.08 & 20 & -98 \\
\hline 4CM38-6 & 1100 & -166.41 & 58 & 174.1 & 42 & -64 \\
\hline 4CM38-7 & 1100 & -198.85 & 100 & - & - & -150 \\
\hline 4CM44-5 & 1100 & -228.02 & 90 & 69.14 & 10 & -152 \\
\hline 4CM44-6 & 1100 & -158.13 & 92 & 162.95 & 18 & -106 \\
\hline 1330CM0-1 & 1330 & -66.2 & 40 & 119.05 & 60 & -28 \\
\hline 1330СM13-1 & 1330 & -156.86 & 84 & 164.35 & 16 & -102 \\
\hline 1330СM13-2 & 1330 & -143.25 & 78 & 106.44 & 22 & -90 \\
\hline 1330СM13-3 & 1330 & -103.66 & 44 & 127.59 & 56 & -30 \\
\hline 1330СМ3-3 & 1330 & -143.02 & 20 & 178.95 & 80 & 12 \\
\hline 1290CM15-3 & 1290 & -188.98 & 86 & 169.2 & 14 & -122 \\
\hline 1290CM23-1 & 1290 & -152.03 & 88 & 115.1 & 12 & -118 \\
\hline 1290СM23-4 & 1290 & -132.15 & 90 & 120.98 & 10 & -96 \\
\hline 1290СМ29-1 & 1290 & -74.27 & 58 & 61.2 & 42 & -58 \\
\hline 1290СМ29-4 & 1290 & -157.69 & 36 & 220.64 & 64 & -4 \\
\hline 1CM0-3 & 1250 & -139.29 & 32 & 169.11 & 68 & -14 \\
\hline 1CM4-5 & 1250 & -150.08 & 82 & 129.09 & 18 & -92 \\
\hline 1CM7-1 & 1250 & -147.19 & 78 & 115.33 & 22 & -96 \\
\hline 1CM8-1 & 1250 & -113.77 & 12 & 184.27 & 88 & 24 \\
\hline $2-3-20-1$ & 1250 & -187.89 & 90 & 138.44 & 10 & -138 \\
\hline $2-3-3-2$ & 1250 & -108.74 & 52 & 168.38 & 48 & -36 \\
\hline $2-3-3-5$ & 1250 & -72.95 & 28 & 216.73 & 72 & 22 \\
\hline $2-3-3-6$ & 1250 & -78.35 & 16 & 209.63 & 84 & 38 \\
\hline $2-3-3-7$ & 1250 & -149.83 & 38 & 186.91 & 62 & -12 \\
\hline 2CM0-1 & 1250 & -114.01 & 36 & 148.89 & 64 & -22 \\
\hline 2CM0-3 & 1250 & -163.93 & 54 & 174.58 & 46 & -54 \\
\hline 2CM2-3-E & 1250 & -111.54 & 86 & 118.64 & 14 & -84 \\
\hline 2CM2-3-L & 1250 & -150.91 & 52 & 151.06 & 48 & -50 \\
\hline 2CM8-1 & 1250 & -94.83 & 26 & 164.84 & 74 & 4 \\
\hline 3СМ0-2 & 1250 & -144.46 & 84 & 77.48 & 16 & -82 \\
\hline 3СМ0-3 & 1250 & -168.71 & 76 & 131.93 & 24 & -94 \\
\hline $3 \mathrm{CM}-4-2$ & 1250 & -126.22 & 100 & - & 0 & -112 \\
\hline 3CM14-1 & 1100 & -73.03 & 16 & 173.05 & 84 & 14 \\
\hline 3СM14-3 & 1100 & -164.98 & 80 & 120.04 & 20 & -108 \\
\hline 3CM14-4 & 1100 & -169.8 & 78 & 129.83 & 22 & -108 \\
\hline 3СM8-1 & 1100 & -184.46 & 94 & 93.2 & 6 & -128 \\
\hline 3СM8-3 & 1100 & -123.3 & 58 & 125.86 & 42 & -58 \\
\hline 4CM18-2 & 1100 & -141 & 54 & 162.4 & 46 & -50 \\
\hline 4CM18-3 & 1100 & -178.51 & 60 & 86.34 & 40 & -80 \\
\hline
\end{tabular}

Note: Samples above 1330CM0-1 are from orebody KT8, other samples are from orebody KT9. P (\%), occurrence rate of P-type pyrite; $\mathrm{N}(\%)$, occurrence of $\mathrm{N}$-type pyrite. 
Table A3. Contents of selected indicator elements of pyrites from orebody KT8 ( $\mu \mathrm{g} / \mathrm{g})$.

\begin{tabular}{|c|c|c|c|c|c|c|c|c|c|}
\hline \multirow{2}{*}{ Level (m) } & \multirow{2}{*}{ Sample No. } & \multicolumn{2}{|c|}{ Supraore Halo } & \multicolumn{3}{|c|}{ Near-Ore Halo } & \multicolumn{3}{|c|}{ Subore Halo } \\
\hline & & $\mathrm{Sb}$ & $\mathbf{B a}$ & $\mathrm{Cu}$ & $\mathrm{Pb}$ & $\mathrm{Zn}$ & $\mathbf{B i}$ & Mo & Co \\
\hline 1250 & 1CM44-1 & 0.68 & 0.88 & 40 & 8.2 & 11.1 & 2.29 & 0.16 & 30 \\
\hline \multirow{2}{*}{1200} & 2CM40-1 & 0.53 & 2.70 & 43 & 2.7 & 16.3 & 3.81 & 0.17 & 65 \\
\hline & 2CM32-4 & 0.98 & 4.43 & 40 & 1.8 & 11.4 & 1.32 & 0.22 & 114 \\
\hline \multirow{10}{*}{1150} & $3-46-1$ & 1.07 & 3.01 & 48 & 10.8 & 10.9 & 0.40 & 0.73 & 326 \\
\hline & 3CM44-6 & 0.40 & 0.51 & 42 & 2.1 & 10.4 & 3.88 & 0.18 & 26 \\
\hline & 3СM38-4 & 3.95 & 1.73 & 67 & 66.6 & 12.6 & 2.21 & 2.24 & 719 \\
\hline & 3СM38-5 & 1.29 & 2.20 & 66 & 2.8 & 13.6 & 3.25 & 0.41 & 747 \\
\hline & 3СМ38-6-E & 6.67 & 1.70 & 172 & 14.6 & 9.6 & 1.70 & 0.26 & 514 \\
\hline & 3CM38-6-L & 1.26 & 0.96 & 94 & 2.3 & 9.1 & 0.22 & 0.05 & 293 \\
\hline & $2-3-38-2$ & 3.96 & 1.23 & 251 & 3.8 & 10.4 & 0.44 & 0.46 & 216 \\
\hline & 3СМ36-2 & 1.05 & 3.00 & 39 & 4.7 & 14.4 & 1.46 & 0.80 & 75 \\
\hline & 3СM36-3 & 3.10 & 1.52 & 62 & 3.0 & 12.5 & 2.73 & 0.92 & 538 \\
\hline & $2-3-24-1$ & 2.21 & 5.08 & 53 & 8.5 & 12.4 & 0.31 & 2.68 & 104 \\
\hline \multirow{22}{*}{1100} & 1100CM46-1 & 0.36 & 0.58 & 34 & 1.8 & 11.4 & 0.09 & 0.32 & 140 \\
\hline & 1100CM46-2 & 0.82 & 0.94 & 36 & 7.8 & 15.4 & 0.28 & 0.66 & 106 \\
\hline & 1100CM44-1 & 0.83 & 2.31 & 42 & 16.3 & 17.3 & 0.60 & 9.31 & 37 \\
\hline & 4CM44-5 & 1.29 & 4.70 & 40 & 4.8 & 12.9 & 1.93 & 0.52 & 93 \\
\hline & 4CM44-6 & 1.24 & 1.15 & 45 & 3.9 & 15.3 & 5.89 & 0.71 & 546 \\
\hline & 2-1100CM42-1 & 1.06 & 2.59 & 34 & 55.6 & 10.6 & 1.91 & 0.57 & 101 \\
\hline & 2-4-40-1 & 0.52 & 2.26 & 36 & 1.2 & 11.3 & 0.11 & 0.20 & 38 \\
\hline & 4CM38-2 & 1.32 & 2.16 & 68 & 4.4 & 15.2 & 4.56 & 0.39 & 410 \\
\hline & 4CM38-5 & 1.28 & 1.55 & 42 & 11.1 & 12.0 & 15.50 & 0.18 & 219 \\
\hline & 4CM38-6 & 0.88 & 4.34 & 45 & 17.7 & 19.2 & 0.89 & 2.41 & 55 \\
\hline & 4CM38-7 & 0.87 & 3.85 & 43 & 590.0 & 22.8 & 7.34 & 0.23 & 57 \\
\hline & 4CM36-4 & 1.82 & 3.36 & 45 & 29.9 & 14.3 & 5.68 & 0.25 & 67 \\
\hline & 4CM36-5 & 0.97 & 2.69 & 45 & 117.0 & 12.9 & 5.97 & 0.36 & 147 \\
\hline & 4CM36-6 & 1.59 & 3.65 & 45 & 385.0 & 19.3 & 13.00 & 0.28 & 116 \\
\hline & 4CM36-8 & 1.99 & 10.00 & 44 & 66.3 & 14.7 & 6.79 & 0.23 & 63 \\
\hline & 1100СМ34-1 & 0.81 & 1.34 & 37 & 2.3 & 11.7 & 0.11 & 0.29 & 53 \\
\hline & 4CM34-2 & 0.53 & 2.24 & 36 & 1.8 & 10.0 & 0.16 & 0.28 & 37 \\
\hline & 1100CM32-1 & 1.87 & 6.86 & 47 & 19.9 & 12.6 & 0.71 & 11.70 & 156 \\
\hline & 4CM28-4 & 3.60 & 1.41 & 58 & 39.1 & 16.6 & 6.76 & 0.77 & 620 \\
\hline & 4CM26-2 & 1.58 & 2.70 & 53 & 14.2 & 13.1 & 0.77 & 0.94 & 67 \\
\hline & 4CM26-3 & 1.12 & 0.91 & 43 & 9.3 & 13.2 & 3.87 & 0.20 & 116 \\
\hline & 4CM24-2 & 1.17 & 0.98 & 50 & 9.4 & 24.2 & 2.89 & 0.16 & 248 \\
\hline
\end{tabular}

Table A4. Contents of selected indicator elements of pyrites from orebody KT9 ( $\mu \mathrm{g} / \mathrm{g})$.

\begin{tabular}{cccccccccc}
\hline \multirow{2}{*}{ Level (m) } & \multirow{2}{*}{ Sample No. } & \multicolumn{2}{c}{ Supraore Halo } & \multicolumn{3}{c}{ Near-Ore Halo } & \multicolumn{3}{c}{ Subore Halo } \\
\cline { 3 - 10 } & & $\mathbf{S b}$ & $\mathbf{B a}$ & $\mathbf{C u}$ & $\mathbf{P b}$ & $\mathbf{Z n}$ & $\mathbf{B i}$ & $\mathbf{M o}$ & Co \\
\hline \multirow{2}{*}{1330} & 1330CM0-1 & 3.35 & 1.24 & 58 & 17.5 & 12.7 & 3.76 & 0.25 & 130 \\
& 1330CM3-3 & 3.28 & 1.60 & 52 & 11.2 & 15.6 & 2.54 & 0.34 & 73 \\
\hline \multirow{3}{*}{1250} & 1CM8-1 & 1.45 & 0.72 & 38 & 2.9 & 11.4 & 6.61 & 0.19 & 84 \\
& 1CM4-5 & 2.42 & 2.40 & 40 & 9.0 & 12.0 & 1.61 & 0.28 & 596 \\
& 1CM0-3 & 2.49 & 1.13 & 39 & 2.6 & 18.7 & 4.50 & 0.17 & 46 \\
& 1CM7-1 & 22.40 & 3.60 & 39 & 4.8 & 11.5 & 5.60 & 0.48 & 55 \\
\hline \multirow{3}{*}{1200} & 2CM8-1 & 1.01 & 1.68 & 43 & 3.2 & 11.8 & 12.10 & 0.23 & 267 \\
& 2CM2-3-E & 2.42 & 1.84 & 40 & 3.4 & 9.9 & 0.68 & 0.39 & 418 \\
& 2CM2-3-late & 0.94 & 0.94 & 37 & 1.5 & 12.6 & 0.32 & 0.11 & 89 \\
& 2CM0-1 & 1.49 & 8.76 & 45 & 54.5 & 29.0 & 10.30 & 0.15 & 80 \\
& 2CM0-3 & 1.02 & 1.61 & 38 & 2.0 & 12.7 & 1.13 & 0.28 & 60 \\
\hline
\end{tabular}


Table A4. Cont.

\begin{tabular}{cccccccccc}
\hline \multirow{2}{*}{ Level (m) } & \multicolumn{2}{c}{ Supraore Halo } & \multicolumn{3}{c}{ Near-Ore Halo } & \multicolumn{3}{c}{ Subore Halo } \\
\cline { 2 - 10 } & Sample No. & Sb & Ba & Cu & Pb & Zn & Bi & Mo & Co \\
\hline \multirow{5}{*}{ 2-3-20-1 } & 1.18 & 1.60 & 37 & 42.6 & 10.3 & 1.47 & 1.25 & 82 \\
& 3CM14-1 & 1.01 & 1.78 & 39 & 23.6 & 39.0 & 4.68 & 0.27 & 109 \\
& 3CM14-3 & 1.17 & 1.05 & 41 & 13.5 & 11.7 & 5.53 & 0.22 & 78 \\
& 3CM14-4 & 1.58 & 0.86 & 42 & 16.9 & 12.3 & 9.58 & 0.22 & 25 \\
& 3CM8-1 & 2.29 & 1.16 & 42 & 38.4 & 14.8 & 0.91 & 0.61 & 344 \\
& 3CM8-3 & 2.09 & 1.31 & 53 & 34.9 & 16.6 & 1.10 & 0.58 & 808 \\
& 3-4-2 & 1.26 & 0.93 & 48 & 4.7 & 11.0 & 0.63 & 0.27 & 2103 \\
& 3CM0-2 & 2.43 & 1.37 & 59 & 16.6 & 12.7 & 5.97 & 2.90 & 696 \\
& 3CM0-3 & 1.44 & 1.03 & 38 & 8.5 & 11.2 & 2.28 & 0.33 & 128 \\
& 3CM7-2 & 4.09 & 1.97 & 78 & 7.9 & 20.0 & 2.18 & 1.33 & 524 \\
\hline \multirow{2}{*}{1100} & 4CM18-2 & 0.49 & 2.21 & 59 & 2.3 & 13.2 & 1.60 & 25.80 & 75 \\
& 4CM18-3 & 0.94 & 0.92 & 44 & 2.1 & 12.0 & 2.22 & 0.28 & 55 \\
\hline
\end{tabular}

\section{References}

1. Su, W.C.; Xia, B.; Zhang, H.T.; Zhang, X.C.; Hu, R.Z. Visible gold in arsenian pyrite at the Shuiyindong Carlin-type gold deposit, Guizhou, China: Implications for the environment and processes of ore formation. Ore Geol. Rev. 2008, 33, 667-679. [CrossRef]

2. Large, R.R.; Danyushevsky, L.; Hollit, C.; Maslennikov, V.; Meffre, S.; Gilbert, S.; Bull, S.; Scott, R.; Emsbo, P.; Thomas, H.; et al. Gold and trace element zonation in pyrite using a laser imaging technique: Implications for the timing of gold in orogenic and carlin-style sediment-hosted deposits. Econ. Geol. 2009, 104, 635-668. [CrossRef]

3. Large, R.R.; Bull, S.W.; Maslennikov, V.V. A carbonaceous sedimentary source rock model for carlin-type and orogenic gold deposits. Econ. Geol. 2011, 106, 331-358. [CrossRef]

4. Deditius, A.; Reich, M.; Kesler, S.E.; Utsunomiya, S.; Chryssoulis, S.; Walshe, J.L.; Hough, R.; Ewing, R.C. The coupled geochemistry of Au and As in pyrite from hydrothermal ore deposits. Geochim. Cosmochim. Acta 2014, 140, 644-670. [CrossRef]

5. Franchini, M.; McFarlane, C.; Maydagán, L.; Reich, M.; Lentz, D.R.; Meinert, L.; Bouhier, V. Trace metals in pyrite and marcasite from the Agua Rica porphyry-high sulfidation epithermal deposit, Catamarca, Argentina: Textural features and metal zoning at the porphyry to epithermal transition. Ore Geol. Rev. 2015, 66, 366-387. [CrossRef]

6. Baker, T.; Mustard, R.; Brown, V.; Pearson, N.; Stanley, C.R.; Radford, N.W.; Butler, I. Textural and chemical zonation of pyrite at Pajingo: A potential vector to epithermal gold veins. Geochem. Explor. Environ. Anal. 2006, 6, 283-293. [CrossRef]

7. Cook, N.J.; Ciobanu, C.L.; Meria, D.; Silcock, D.; Wade, B. Arsenopyrite-pyrite association in an orogenic gold ore: Tracing mineralization history from textures and trace elements. Econ. Geol. 2013, 108, 1273-1283. [CrossRef]

8. Hu, C.Y. Characteristics of trace elements, thermoelectricity and crystal form of pyrite. Geoscience 2001, 15, 238-241.

9. Chen, H.Y.; Li, S.R.; Zhang, X.B.; Zhou, Q.F.; Zhang, Y.Q.; Liu, Z. Thermoelectic character of pyrite from Jinqingding gold deposit in eastern Shandong Province and its significance. Miner. Depos. 2010, 29, 1125-1137. (In Chinese with English abstract)

10. Wang, J.P.; Liu, J.J.; Carranza, E.J.M.; Liu, Z.J.; Liu, C.H.; Liu, B.Z.; Wang, K.X.; Wang, H. A possible genetic model of the Shuangwang hydrothermal breccia gold deposit, Shaanxi Province, central China: Evidence from fluid inclusion and stable isotope. J. Asian Earth Sci. 2015, 111, 840-852. [CrossRef]

11. Shi, Z.L.; Liu, J.X.; Fan, S.C. Geological Characteristics and Genesis of the Shuangwang Gold Deposit, Shaanxi Province; Science and Technology Publishing House of Shaanxi: Xi'an, China, 1989; pp. 1-116. (In Chinese)

12. Zhang, Z.H.; Mao, J.W.; Li, X.F. Geology, geochemistry and metallogenic mechanism of the Shuangwang breccia type gold deposit. Miner. Depos. 2004, 23, 241-252. (In Chinese with English abstract) 
13. Li, S.G.; Xiao, Y.L.; Liu, D.L.; Zhang, Z.; Zhang, R.; Liu, D.; Hart, S.R.; Ge, N. Collision of the North China and Yangtze Blocks and formation of coesite-bearing eclogites: Timing and processes. Chem. Geol. 1993, 109, 70-89.

14. Dong, Y.P.; Zhang, G.W.; Franz, N.; Liu, X.; Genser, J.; Hauzenberger, C. Tectonic evolution of the Qinling Orogen, China: Review and synthesis. J. Asian Earth Sci. 2011, 41, 213-237. [CrossRef]

15. Ratschbacher, L.; Hacker, B.R.; Calvert, A.; Webb, L.E.; Grimmer, J.C.; McWilliams, M.O.; Ireland, T.; Dong, S.W.; Hu, J.M. Tectonics of the Qingling (Central China): Tectonostratigraphy, geochronology, and deformation history. Tectonophysics 2003, 366, 1-53. [CrossRef]

16. Lai, S.C.; Zhang, G.W.; Yang, Y.C.; Chen, J.Y. Geochemistry of the ophiolite and island-arc volcanic rocks in the Mianxian-Lueyang suture zone, southern Qinling and their tectonic significance. Chin. J. Geochem. 1998, 18, 39-50.

17. Goldfarb, R.J.; Taylor, R.D.; Collins, G.S.; Goryachev, N.A.; Orlandini, O.F. Phanerozoic continental growth and gold metallogeny of Asia. Gondwana Res. 2014, 25, 48-102. [CrossRef]

18. Li, X.Z.; Yan, Z.; Lu, X.X. Granites of Qinling-Dabie Orogen; Geological Publishing House: Beijing, China, 1993; pp. 1-215. (In Chinese)

19. Li, Y.J.; Ding, S.P.; Chen, Y.B.; Li, Z.W.; Dong, J.G. New knowledge on the Wenquan granite in western Qinling. Geol. Miner. Resour. South China 2003, 19, 1-8. (In Chinese with English abstract)

20. Zhang, H.F.; Jin, L.L.; Zhang, L.; Nigel, H.; Zhou, L.; Hu, S.H.; Zhang, B.R. Geochemical and Pb-Sr-Nd isotopic compositions of granitoids from western Qinling belt: Constraints on basement nature and tectonic affinity. Sci. China Ser. D 2007, 50, 184-196. [CrossRef]

21. Zeng, Q.T.; McCuaig, T.C.; Hart, C.J.R.; Jourdan, F.; Muhling, J.; Bagas, L. Structural and geochronological studies on the Liba goldfield of the West Qinling Orogen, Central China. Miner. Depos. 2012, 47, 799-819. [CrossRef]

22. Li, Z.P.; Peters, S.G. Comparative Geology and Geochemistry of Sedimentary-Rock-Hosted (Carlin-Type) Gold Deposits in the People's Republic of China and in Nevada, USA; U.S. Geological Survey: Denver, CO, USA, 1998; pp. 98-466.

23. Mao, J.W.; Qiu, Y.M.; Goldfarb, R.J.; Zhang, Z.C.; Garwin, S.; Reng, F.S. Geology, distribution, and classification of gold deposits in the western Qinling belt, central China. Miner. Depos. 2002, 37, 352-377. [CrossRef]

24. Liu, J.J.; Liu, C.H.; Carranza, E.J.M.; Li, Y.J.; Mao, Z.H.; Wang, J.P.; Wang, Y.H.; Zhang, J.; Zhai, D.G.; Zhang, H.F.; et al. Geological characteristics and ore-forming process of the gold deposits in the western Qinling region, China. J. Asian Earth Sci. 2015, 103, 40-69. [CrossRef]

25. Wang, Z.Q.; Yan, Q.R.; Yan, Z. New division of the main tectonic units of the Qinling Orogenic Belt, Central China. Acta Geol. Sin. Engl. 2009, 83, 1527-1546. (In Chinese with English abstract)

26. Wang, H. The Features of Magmatic Rocks in Shuangwang Gold Mine, Shanxi Province and Its Implication on Gold Mineralization. Master's Thesis, China University of Geosciences, Beijing, China, 2012; pp. 1-103. (In Chinese).

27. Zeng, Q.S.; Wang, J.C.; Chen, G.H. Formation of gold-bearing hydrofracturing breccia bodies in tectonic lenses: A case study on the Shuangwang gold deposit, Shaanxi, China. Geotecton. Metall. 2005, 29, 93-106.

28. DZ/T0223-2001. Geology Mineral Industry Standard of P.R. China: The General Analysis Rules for Inductively Coupled Plasma Mass Spectrometry; Geological Press: Beijing, China, 2001. (In Chinese)

29. Li, H.; Wang, Z.N.; Li, F.G. Ideal models of superimposed primary halos in hydrothermal gold deposits. J. Geochem. Explor. 1995, 55, 329-336. [CrossRef]

30. Shao, J.L. Exploration Mineralogy of Gold Deposits; China University of Geosciences Press: Wuhan, China, 1988; pp. 38-45. (In Chinese)

31. Su, W.C. A pyroelectricity study on pyrite and its prospecting significance in Lannigou gold deposit, southwestern Guizhou. Gold Geol. 1997, 3, 7-12. (In Chinese)

32. Zhao, H.D.; Xing, Y.P. A preliminary exploration of the relationship between pyroelectric effect and gold content of pyrite. Acta Miner. Sin. 1988, 8, 39-45. (In Chinese with English abstract)

33. Li, H.B.; Zeng, L.F. The pyrite's typomorphic characteristics in gold deposit. Contr. Geol. Miner. Resour. Res. 1993, 20, 199-203. (In Chinese with English abstract) 
34. Murowchick, J.B.; Barnes, H.L. Effects of temperature and degree of supersaturation on pyrite morphology. Am. Mineral. 1987, 72, 1233-1242.

35. Li, S.R.; Shao, W.; Cheng, G.Y.; Sun, D.S. Study on the morphology of pyrite from Rushan gold mines, Jiaodong region. Contrib. Geol. Miner. Resour. Res. 1994, 9, 79-86.

(C) 2019 by the authors. Licensee MDPI, Basel, Switzerland. This article is an open access article distributed under the terms and conditions of the Creative Commons Attribution (CC BY) license (http://creativecommons.org/licenses/by/4.0/). 